\title{
NITROGEN USE EFFICIENCY IN CEREALS UNDER HIGH PLANT DENSITY: MANUFACTURING, MANAGEMENT STRATEGIES AND FUTURE PROSPECTS
}

\author{
SHER, A. ${ }^{1}-$ ZHANG, L. G. ${ }^{2}-$ NOOR, M. A. ${ }^{3}$ - NADEEM, M. ${ }^{4}-$ ASHRAF, U. ${ }^{5}-$ BALOCH, S. K. ${ }^{6}-$ \\ AMEEN, A. ${ }^{7}-$ YUAN, X. Y. $.^{*}-$ GUO, P. Y. ${ }^{1 *}$ \\ ${ }^{1}$ Key Laboratory of Crop Chemical Regulation and Chemical Weed Control, College of \\ Agronomy, Shanxi Agricultural University, Taigu, Shanxi, China \\ ${ }^{2}$ Institute of Crop Sciences, Shanxi Academy of Agricultural Sciences, Taiyuan, China \\ ${ }^{3}$ Institute of Crop Sciences, Chinese Academy of Agricultural Sciences, Key Laboratory of Crop \\ Physiology and Ecology, Ministry of Agriculture, 100081 Beijing, China \\ ${ }^{4}$ School of Agronomy, Anhui Agricultural University, Hefei, China \\ ${ }^{5}$ Department of Botany, University of Education, Faisalabad-Campus, Faisalabad 38000, \\ Punjab, Pakistan \\ ${ }^{6}$ College of Agriculture, Shanxi Agricultural University, Taigu, Shanxi, China \\ ${ }^{7}$ Department of Agronomy, Faculty of Agriculture, Gomal University, Dera Ismail Khan 29050, \\ Pakistan \\ *Corresponding authors \\ e-mail: yuanxiangyang200@163.com; pyguo126@126.com
}

(Received $16^{\text {th }}$ Oct 2018; accepted $28^{\text {th }}$ Jan 2019)

\begin{abstract}
Increasing the crop yield is very important and depends relatively on high plant density. The high grain yield per unit area of cereals is due to the optimum plant density. In this review, recent improvements and future insights to obtain better information for the regulation of nitrogen use efficiency in cereals under high plant density are presented. An updated knowledge of the basic mechanisms controlling plant nitrogen interaction is very important in cereals, to increase nitrogen use efficiency and for decreasing high cost of fertilizers, to obtain high output. In view of this fact, we should emphasize to develop plant morpho-physiological, agronomic and molecular studies which focuses on phenomics, genomics, and metabolite profiling to understand comprehensive knowledge of the different steps of nitrogen uptake, assimilation, and recycling under high plant density in cereals. A very important piece of information is provided on understanding of the physiological assimilation of $\mathrm{N}$ under different environmental conditions in cereals under different plant densities that has been improved through the use of different strategies for future research. According to the global economic and environmental constraints for future, agronomic and physiological principles and application which were adapted to less fertilizer inputs are discussed under high plant density.
\end{abstract}

Keywords: cereals, NUE, plant density, nitrogen management, physiological mechanism

\section{Introduction}

Cereals are sine qua non for current and projected human food security being staple food nearly in every region and country. Across the globe, merely 5\% of staple derives from root crops like cassava, yams and potato, while the rest is provided by cereals with a range of health benefits. To ensure and secure food security on sustainable basis, cereals have to produce grains with many-fold larger quantity. Further increase in yield 
would largely come from optimal planting density in field (Tokatlidis et al., 2011; Sher et al., 2017, 2018). Increasing the planting density of cereals is an agronomical task/deed/process has evolved over the time and this management practice has changed from the past six decades (Tollenaar, 1992; Sher et al., 2016; Noor, 2017). For example in USA Corn Belt, maize planting density has evolved from 3 plants $\mathrm{m}^{-2}$ to 8 plants $\mathrm{m}^{-2}$ in 85 years from 1930 to 2015 ( $\mathrm{Li}$ et al., 2015) which caused many fold increase in average yield.

In the USA hybrids of central Iowa have increased nearly $79 \mathrm{~kg} \mathrm{ha}^{-1}$ annually (Duvick, 1996). These yield escalations have occurred however mean yield per plant has not been changed significantly, increased by just an average of $0.05 \mathrm{~kg} \mathrm{plant}^{-1}$ over the past 40 years (USDA, 2010) while average plant population has increased by an average 720 plants ha $^{-1}$ per year over the past 44 years (USDA, 1965-2009). In European countries where climate is heterogeneous than USA row spacing for planting density of maize vary between $70-75 \mathrm{~cm}$ to facilitate intensive cultivation (Sharratt and McWilliams, 2005). Developing countries produced lower grains of maize from a unit of land than developed countries though environmental and irrigation are satisfactory for maize production. Therefore the main constrain is low plant density per unit of land than those of developed countries. Mean planting density of $58000 \mathrm{ha}^{-1}$ in developed countries is about two times less intensive than current cultivation stand density in developed countries. Grain yield per unit land area is the product of grain yield plant ${ }^{-1}$ and number of plants per unit area (Hashemi et al., 2005). Maximum yield per unit area may be obtained by growing cereals hybrids that can withstand high plant density, up to 100,000 plants ha ${ }^{-1}$ (Huseyin et al., 2003). Growing hybrid by maintaining high density may causes a radical decline in grain yield as these hybrids can be susceptible to high stand density. In such hybrids, one-eared bearing pattern, recumbent leaf, plant height and large-type plants are the reasons of non-significant tolerance against high plant population (Tang et al., 2018; Hou et al., 2019). On other hand, developed countries grow hybrids that are characterized by high yielding ability per unit land due to prolificacy, early silking and tasseling, short anthesis-silking interval (ASI), more grain filling period, rare barren stalks backed them to adopt high density field environments. Likewise genotypes with erect leaves intercept light more efficiently and are very desirable for increased population densities (Radenovic et al., 2007). Therefore, there is a great genetic difference in grains production by cereals owing to their response to altering planting density (Liu et al., 2004). Main purpose of higher plant densities is to increase grain yield or biomass over per unit of land which make the cropping system more efficient over a piece of land. In absence of environmental stresses, grain production is directly proportional to amount of solar radiation intercepted by plants. Thus, efficient light harvesting is of paramount importance for plants growing in competition in dense stands under natural conditions (Pearcy et al., 2004; Valladares and Niinemets, 2008). The plant density has been evolving for decades, but now more enhancements in density fails to upsurge grains production has been rising steadily. But advancement in hybrids to tolerate high canopy still can attain the goal. Researchers believes that high densities like 90,000 plants ha ${ }^{-1}$ are still below potential maximum yield densities, indicating even higher tolerance to stand density may be possible in advanced hybrids (Widdicombe and Thelen, 2002). Planting density is also critical for the wheat because it directly affects the morphological parameters like number of ears per unit area. Currently, the plant density for the wheat ranges from 250 to 400 viable 
seeds. This is based on the hybrid cycle, as well as its dual ability as a forage and grain crop (Comissão et al., 2007).

In the rice production system higher densities are helpful in suppression of weeds (Ahmed et al., 2016). But extra cost on more seeds for high seedling density should be set off with more yield. Sorghum is most favorable for those areas where water availability is limited as it produced grains with less water compared to other cereals. Plant population of sorghum influence both tillering and panicle weight. The greater densities did support fewer tillers per plant. This response is due to the competitiveness of the stand and is normally associated with reduced weight of the inflorescence (Gardner et al., 2010). Yield response of barley also varies with changing planting densities (Soleymani et al., 2011). Therefore, optimal grains production come from optimal planting stand by taking into account the specific set of environmental conditions and available resources including the particular cultivar characteristic which are responsible for tolerance to dense canopy architecture. Several factors, such as hybrid maturity group, water availability, soil fertility and row spacing (Sangoi et al., 2002) are crucial in determining proper plant number per unit area. In this study the response of cereals to plant population and nutrient management are presented and future prospects and insights are discussed.

\section{Importance of nitrogen use efficiency}

For food security it is necessary to enhance NUE in cereal crops at low input of fertilizers (White and Brown, 2010). Cereal crops need large amount of nitrogen to produce optimum yield and for which NUE is calculated is below 50\% (Wang et al., 2018; Zhu, 2000; Ruan and Johnson, 1999). Irrigation, fertilizer and soil management practices are very important to enhance the crop yield (Ruan and Johnson, 1999).

Nitrogen plays an important role in crop growth and yield (Noor, 2017). Among the major plants nutrient $\mathrm{N}$ is taken up by the plants in largest amount. $\mathrm{N}$ is an essential component of plant growth (protein, enzymes, DNA, RNA) and photosynthesis i.e. chlorophyll. Symbiosis process in leguminous crops provides more nitrogen to soil which ultimately increased crop yield. Plants use nitrogen in the form of ammonium and nitrate (Fig. 1). Excess of nitrogen adversely affect plant growth and environment and surface nitrogen often leads to its contamination, eutrophication which later produces a decline in oxygen content of water. To improve NUE in cereals, some strategies need to apply for example $\mathrm{N}$ management, plant breeding and genetics. NUE is economically and also environmentally beneficial to enhance irrigation use efficiency, diminish soil erosion, reduces the pest infestation, to maintain soil texture, increase soil organic matter and humidity, less reliance on agricultural chemicals and improve crop NUE (Noor, 2017; Halvorson et al., 2001; Riedell et al., 2009).

The plant life cycle in response to the nitrogen management is divided into two parts: the vegetative part and the reproductive part. During vegetative growth, smaller roots and leaves respond as sink organs before flowering and then reduced by the nitrate assimilatory pathway (Hirel and Lea, 2001). The amino acids are further used for the synthesis of enzymes and proteins which are involved in growing plant architecture and the different components of the photosynthetic pigments, in $\mathrm{C} 3$ species $50 \%$ of the total soluble leaf protein can be represent alone by Rubisco (ribulose 1,5- isphosphate carboxylase) (Mae, 1997) and 20\% in C4 species. 
Before anthesis in wheat, $60-95 \% \mathrm{~N}$ comes from the remobilization of $\mathrm{N}$ stored in young roots and shoots (Palta and Fillery, 1995). Post-flowering $\mathrm{N}$ uptake and $\mathrm{N}$ translocation to the grain is available in a very less quantity. Under N-deficient conditions the size and the $\mathrm{N}$ content of the grain significantly decreased (Dupont and Altenbach, 2003). Nitrogen (N) deficiency, is one of the major problem diminishing crop growth (Tanner et al., 1993; Teklu and Hailemariam, 2009). Three split applications at anthesis showed significant result for Higher NHI (Jan et al., 2010). It is not clear that storage protein synthesis and plant $\mathrm{N}$ availability or that decreases the determination of grain yield and protein synthesis $\mathrm{N}$ applications in wheat are generally calculated by the total $\mathrm{N}$ budget method. Until tillering, the soil supplies nitrogen to the plant. Three applications are generally recommended: one at tillering (50-80 kg ha-1), one at the beginning of stem elongation (around $50 \mathrm{~kg} \mathrm{ha}^{-1}$ ), and one at the second node stage $\left(40-50 \mathrm{~kg} \mathrm{~h}^{-1}\right)$. SPAD meter is a potential instrument used for predicting grain $\mathrm{N}$ requirements in cereals (Lopez-Bellido et al., 2004). In rice crop same pattern of $\mathrm{N}$ management exists but the plant mostly uses ammonium instead of nitrate. Vegetative organs uses the remobilized N 70-90\% of the total panicle N (Mae, 1997; Tabuchi et al., 2005). Crop residues in rice belt farming patterns have small or no short-term benefits on rice yield (Thuy et al., 2008). In the field, at early growth phase and tillering 40 to $110 \mathrm{~kg} \mathrm{~N} \mathrm{ha}^{-1}$ used in the form of ammonium or urea. At panicle primordial stage and the late stage of spikelet initiation, additional top-dressing $N\left(15-45 \mathrm{~kg} \mathrm{ha}^{-1}\right)$ is applied and is effective for spikelet production. Sink size of rice crop is little effected by $\mathrm{N}$ uptake. During the grain-filling stag, in a leaf blades $\mathrm{N}$ is accumulated and large part used by the grain and that contributes to grain $\mathrm{N}$ protein synthesis (Mae, 1997). Plant density and nitrogen use efficiency of cereals are represented in Table 1.

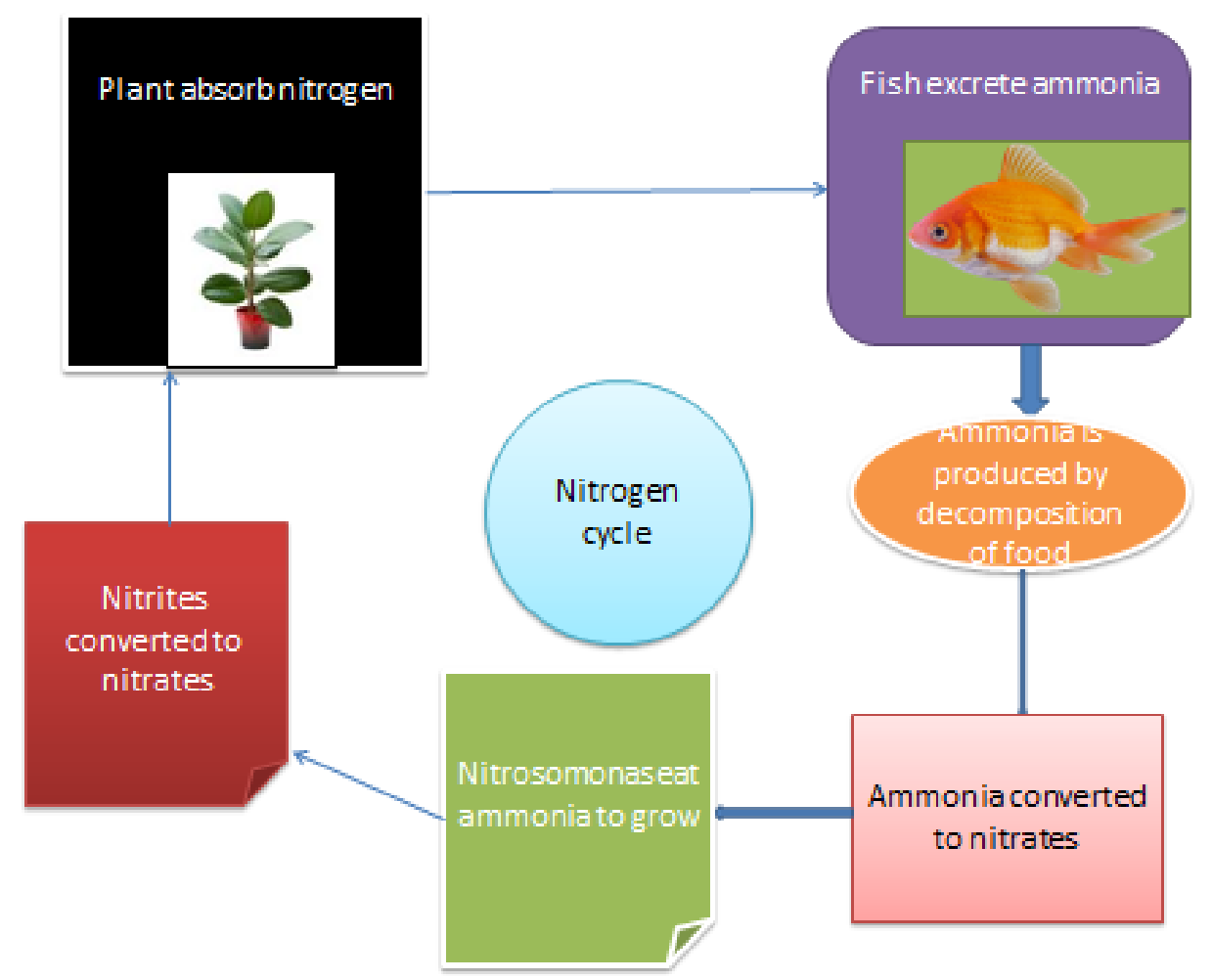

Figure 1. Nitrogen cycle in agricultural systems. 


\section{Physiological response of cereals to nitrogen use efficiency}

Good et al. (2004) and Lea and Azevedo (2006), defined nitrogen use efficiency as nitrogen in grain per total $\mathrm{N}$ uptake. NUE is further divided into two parts i.e. uptake and utilization efficiency (Moose and Below, 2009). Winter wheat response to next crop and crop management the effect of next crop on the $\mathrm{N}$ uptake of the following crop has long been studied (Anderson, 2008).

Table 1. Nitrogen use efficiency for different plant density and nitrogen regimes

\begin{tabular}{c|c|c|c|c|c|c}
\hline Planting density & Crop & Seed rate/PD* & Yield & NUE & Ref & Exp. duration \\
\hline LD & Wheat & $180 \mathrm{~kg} \mathrm{ha}-1$ & $2643 \mathrm{~kg} / \mathrm{ha}$ & 22.5 & Gao et al., 2009 & 2003 \\
HD & Wheat & $225 \mathrm{~kg} \mathrm{ha}-1$ & 2657 & 25.9 & Gao et al., 2009 & 2003 \\
LD & Wheat & $180 \mathrm{~kg} \mathrm{ha}-1$ & $3,477 \mathrm{~kg} / \mathrm{ha}$ & 45.3 & Gao et al., 2009 & $2003-4$ \\
HD & Wheat & $225 \mathrm{~kg} \mathrm{ha}-1$ & 3,745 & 54.6 & Gao et al., 2009 & $2003-4$ \\
ND & Maize & $27 \mathrm{~cm}$ & $3.51 \mathrm{~g} / \mathrm{plant}$ & 46.51 & Jiang et al., 2013 & 2007 \\
HD & Maize & $6 \mathrm{~cm}$ & 3.24 & 49.57 & Jiang et al., 2013 & 2007 \\
ND & Maize & $27 \mathrm{~cm}$ & 3.57 & 46.82 & Jiang et al., 2013 & $2007-2008$ \\
HD & Maize & $6 \mathrm{~cm}$ & 3.40 & 50.87 & Jiang et al., 2013 & $2007-2008$ \\
ND & Wheat & $300 \mathrm{plants} / \mathrm{m}^{2}$ & $676.40 \mathrm{~g} / \mathrm{m} 2$ & $1.3 \mathrm{~kg} / \mathrm{ha}$ & Jamaati-e-Somarin et al., 2010 & 2008 \\
ND & Wheat & 350 & 753.42 & $2.1 \mathrm{~kg} / \mathrm{ha}$ & Jamaati-e-Somarin et al., 2010 & 2008 \\
ND & Wheat & 400 & 909.63 & $2.4 \mathrm{~kg} / \mathrm{ha}$ & Jamaati-e-Somarin et al., 2010 & 2008 \\
LD*LN & Maize & $54,000 \mathrm{p} / \mathrm{hec}$ & $138.6 \mathrm{~g} / \mathrm{plant}$ & 8.68 & Ciampitti \& Vyn, 2011 & 2009 \\
LD*HN & Maize & $54000 \mathrm{p} / \mathrm{h}$ & $142.6 \mathrm{~g} / \mathrm{p}$ & 5.18 & Ciampitti \& Vyn, 2011 & 2009 \\
MD*LN & Maize & $79,000 \mathrm{p} / \mathrm{h}$ & $124.2 \mathrm{~g} / \mathrm{p}$ & 8.89 & Ciampitti \& Vyn, 2011 & 2009 \\
MD*HN & Maize & $79,000 \mathrm{p} / \mathrm{h}$ & $145.9 \mathrm{~g} / \mathrm{p}$ & 10.47 & Ciampitti \& Vyn, 2011 & 2009 \\
HD*LN & Maize & $104,000 \mathrm{p} / \mathrm{h}$ & $102.3 \mathrm{~g} / \mathrm{p}$ & 18.55 & Ciampitti \& Vyn, 2011 & 2009 \\
HD*HN & Maize & $104,000 \mathrm{p} / \mathrm{h}$ & $105.8 \mathrm{~g} / \mathrm{p}$ & 10.54 & Ciampitti \& Vyn, 2011 & 2009 \\
\hline
\end{tabular}

$\mathrm{LD}=$ low density, $\mathrm{HD}=$ high density $\mathrm{MD}=$ medium density

$\mathrm{NHI}$ is defined as the ratio of grain protein content to the nutritional quality (Sinclair, 2004). Jan et al. (2010) reported that the higher NHI in the three split application at anthesis gave significant result. The genomics for grain composition indicates that grain yield and protein concentration in most grain crops has been reduced by an apparent inverse genetic relationship (Simmonds, 1995), including wheat (Canevara et al., 1994), oilseed rape (Brennan et al., 2000; Jackson, 2000) and maize (Feil et al., 1990). A negative regression is used to predict higher grain protein content among wheat line (Oury et al., 2003; Kade et al., 2005).

High yielding and high protein varieties are used to determine negative control present between yield and grain protein content. This is also helpful for understanding the comparison of $\mathrm{N}$ uptake and $\mathrm{N}$ use for protein deposition under less and high $\mathrm{N}$ condition (Uribalarrea et al., 2007). Modern varieties showed greater NUE than older ones (Sylvester-Bradley and Kindred, 2009), but this phenomena has not been identified. Crop management, fertilizer application methods to develop high yielding varieties through breeding are the two ways to enhance NUE for example root system can be modify in up taking the nitrate from the below soil that have negative effects on the uptake efficiency of phosphate, which is present in upper soil. 


\section{Impact of nitrogen use efficiency and plant density on photosynthesis}

To increase light interception on plants to improve photosynthesis there is a tight relationship among radiation use efficiency (RUE), leaf $\mathrm{N}$ distribution, leaf photosynthetic pigments and $\mathrm{N}$ supply and plant population (Gastal and Lemaire, 2002) when $\mathrm{C} 3$ or $\mathrm{C} 4$ crop species are studied. It is very important to study the level of $\mathrm{CO}_{2}$ saturation of Rubisco. As an example of a tillering Gramineae species, Bos and Vos (2000) analysed for wheat which morphological leaf components were influenced by plant population and which mechanisms were involved. They reported that the most significant effect of higher plant population on leaf area per plant was the absence of later formed tillers. When a species does not form tillers, plant density can only affect the growth of leaves on the main stem. A study into the effects of environmental factors on the morphological development of such a plant type could lead to a better understanding of mechanisms involved in the effects of plant density on leaf-area development. Moreover, at higher plant densities, leaf area per plant is decreased in later phases of growth (Hay and Walker, 1989).

In both Sorghum and maize $\mathrm{N}$ uptake capacity depends leaf senescence is the cause of increased photosynthetic activity (Borrel et al., 2001). For improving the characterization of plants that are stay-green, $\mathrm{N}$ uptake, $\mathrm{N}$ assimilation and $\mathrm{N}$ recycling of the fine regulatory mechanisms is very important (Rampino et al, 2006). To know more about the physiological and molecular basis of the stay-green phenotype, further research is needed. To characterize whether such a phenotype are used when $\mathrm{N}$ fertilization is decreased and when water resources are decreased in relation to nitrogen availability, root $\mathrm{N}$ uptake capacity and architecture (Borrell et al., 2000).

\section{Plant N economy and their species specificities}

Nitrogen $(\mathrm{N})$ deficiency is big threat for limiting wheat production and yield (Tanner et al., 1993; Teklu and Hailemariam, 2009). In maize (Zea mays L.) before silking about $45-65 \%$ of the grain $\mathrm{N}$ already exists in stover and the remaining 35-55\% of the grain N produces from post-silking N (Ta and Weiland, 1992; Rajcan and Tollenaar, 1999; Gallais and Coque, 2005). To obtain maximum yield, one application of $\mathrm{N}$ fertilizer is recommended at sowing, ranging from 100 to $240 \mathrm{~kg} \mathrm{~N}$ ha $^{-1}$. Chlorophyll meter is the best instrument to estimate leaf $\mathrm{N}$ in maize crop (Chapman and Baretto, 1997).

Barley (Hordeum vulgare L.) is the fourth major crop in cereals. Due to genetic, physiological and agronomic studies it is an established model plant (Raun and Jonhson, 1999). However, $\mathrm{N}$ uptake and assimilation through biochemical and molecular mechanisms and recycling is best in this crop. Future improvements require studying $\mathrm{N}$ fertilizer levels and timing of application to achieve best grain yield and good quality of protein content. However, symbiotic $\mathrm{N}$ crop species contributes half of the amount of $\mathrm{N}$ applied in inorganic $\mathrm{N}$ fertilizers (Smil, 2006).

\section{Plant development stages related to nutrition and plant density}

Cereal yield is linearly correlated to high plant density. Improved morphology was the key for promoting light use efficiency per plant (Yu et al., 1998; Li and Li, 2004) which influenced canopy architecture, light interception and yield (Maddoni et al., 2001; Stewart et al., 2003; Tollenaar et al., 2006; Li and Wang, 2010). Superoptimal 
planting densities can affect canopy architecture particularly during the period bracketing silking and can lead to reduce the yield (Tollenar and Wu., 1999; Maddoni et al., 2001; Christopher et al., 2009). Increasing panting density accelerated leaf senescence (Tethio-Kagho and Gardner, 1988), increased the shading of leaves (Hashemi-Dezfouli and Herbert, 1992), and reduced the net assimilation of individual plants. An increase in plant population of 2-13 plants per $\mathrm{m}^{2}$ reduced net assimilation per plant from 0.85 to $0.11 \mathrm{mg} \mathrm{CO}_{2} \mathrm{~m}^{-2} \mathrm{~s}^{-1}$, but increased grain yield per area (Dwyer et al., 1991). This enhancement in grain yield can be explained by the increase in LAI and net crop assimilation rate. Corn cultivars having erect leaves are very desirable for increased population densities, which increases light interception (Radenovic et al., 2007).

In plants $\mathrm{N}$ availability influences several developmental processes the number i.e. leaves and their rate of appearance (Snyder and Bunce, 1983; Mae, 1997), and the number of tillers (Vos and Biemond, 1992; Trapani and Hall, 1996) are reduced under $\mathrm{N}$-limiting conditions both in spring wheat. The valuable contribution of Arabidopsis research community is to verifying the connection between $\mathrm{N}, \mathrm{N}$ uptake and root development (Remans et al., 2006); However, recent studies have suggested that an increased acidification capacity of the rhizosphere could be targeted to increase nitrate uptake and improve NUE in addition, the NUE of agricultural system may be improved if plants could maintain internal nutrient concentrations and optimal growth with a lower outside concentration in the soil. Therefore understanding the response mechanisms of NAcE to nutrient deficiencies may improve the ability of crops to tolerate lower nutrient concentrations in the soil and thereby save fertilizer and reduce potential pollution. All abbreviations are added in Table 2.

Table 2. Abbreviations

\begin{tabular}{c|c}
\hline LD & Low density \\
MD & Medium density \\
HD & High medium density \\
NUE & Nitrogen Use efficiency \\
NHI & Nitrogen harvest index \\
HHV & High heat value \\
AN & Ammonium nitrate \\
CN & calcium ammonium nitrate \\
\hline
\end{tabular}

\section{Manufacturing and cost of production of nitrogenous fertilizers}

The products of the fertilizer industry are unique and different, every product needs different production processes. Fertilizer industries use many input as raw materials for example (energy, electricity natural gas, and other hydrocarbons), mineral phosphate, potassium salts, sulphur ammonia and acids (phosphoric, sulphuric, nitric), blending mixtures. There are different small companies' uses basic fertilizer materials to process, blends and mix compounds, which may or may not be further processed into mixtures, blends or compound to make fertilizers. Due to this complex process, basic fertilizer material such as phosphate, potassium salts, sulphur and ammonia should be used to the soil directly, according to this scenario, one company raw material may be another company product. 


\section{Cost of production for nitric acid, ammonium nitrate (AN) and calcium ammonium $(\mathrm{CN})$ nitrate production}

Basic inputs per ton of $\mathrm{AN}$ in modern plants include $0.21 \mathrm{t} \mathrm{NH} 3,0.78 \mathrm{t} 100 \% \mathrm{HNO}_{3}$ and $25-40 \mathrm{kWh}$ of electricity. Steam and turbine power are according to the nitric acid concentration. Thus, the net steam requirement may vary from zero to $50 \mathrm{~kg} / \mathrm{t}$, and it depends if final product is only AN solution, steam may be exported (UNEP et al., 1998). Anhydrous ammonia production is represented in Figure 2.

The complete $\mathrm{N}$ budget is calculated as a function of $\mathrm{N}$ mineralization and the soil nitrate levels are used at the beginning of the season. Nitrogen mineralization are calculated as a function of soil texture and organic matter content. Most agricultural soils contain less naturally occurring plant available nitrogen to meet the needs of a crop throughout the growing season. Supplementary nitrogen applications are normally made each year to meet crop demand.

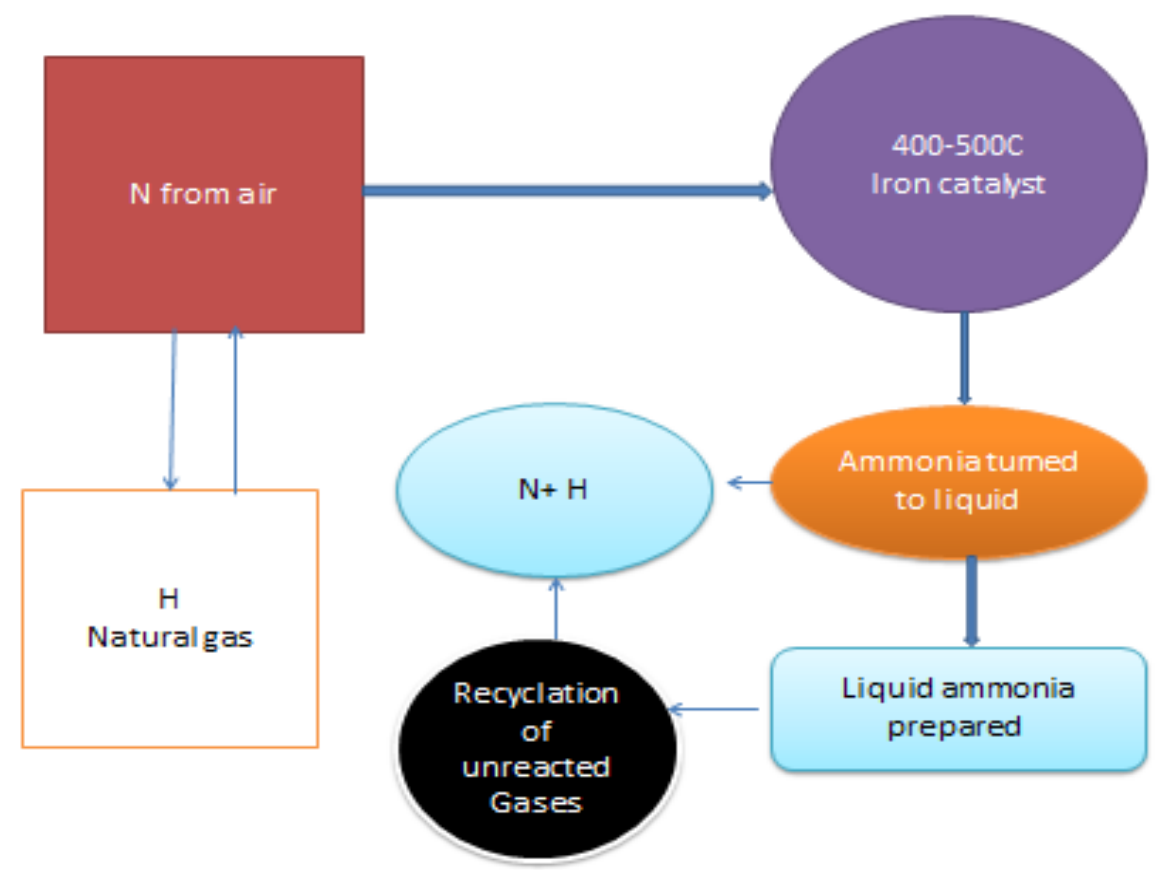

Figure 2. Anhydrous ammonia production

\section{Strategies and practices to improve nitrogen use efficiency}

Soil physical properties are very important to improve nitrogen use efficiency for example, soil texture, soil structure, organic matter.

Soil texture: Top soil texture is very important to determine lime requirement.

Soil structure: To obtain optimum economic yields, crops need sufficient nutrients and water from the soil through roots. To maintain good soil structure root growth is very important soil parameter, such as compaction.

Soil organic matter: Soil organic matter is a vital source of $\mathrm{N}$ used by crops. Organic matter consists of stable material called humus that has cumulated over a period of time.

There are different ways and procedure which are used to lower the price of fertilizers at farm-gate and to reduce the farmers' perception of the risk in the use of fertilizers by: (i) Hashemi-Dezfouli and Herbert (1992) sting in distribution 
infrastructure; (ii) Researching innovative ideas to avoid losses and to provide finance; (iii) Encouraging sub regional measurement for country-level fertilizer manufacturing companies, facilities and/or procurement; and (iv) Encouraging dialogue between different agencies to arrive at a common approach to increase nitrogen use efficiency. Nitrogen management for intensification of cereals is widely researched topic across the globe.

Soil quality and NUE: Cycling of nutrients depends on the quality of agricultural soils, either directly through their capacity to receive nutrients and to convert them into or keep them in forms that are available to crops, or indirectly by governing the productivity and harvestability of crops and thereby the effective capture of nutrients from soils (Giller et al., 1997; Harris et al., 2011; Keesstra et al., 2016). Generally to improve nitrogen use efficiency following points should be considered (1) fertilizer use timing (2) Risk of N loss; (3) Placing N close to the period of maximum crop growth; (4) Even application of fertilizer and Fertilizer application rate; (5) Nitrogen fertilizer sources; (6) Application methods (7) Additives to reduce losses; (8) Managing nitrogen from manure; (9) Promoting efficient uptake and special consideration. Agronomic factors affecting plant population are (i) cultivar, (ii) length of the growing season, (iii) time of planting, (iv) water availability, (v) row spacing. Management and sources of nitrogen fertilizers are represented in Figure 3.

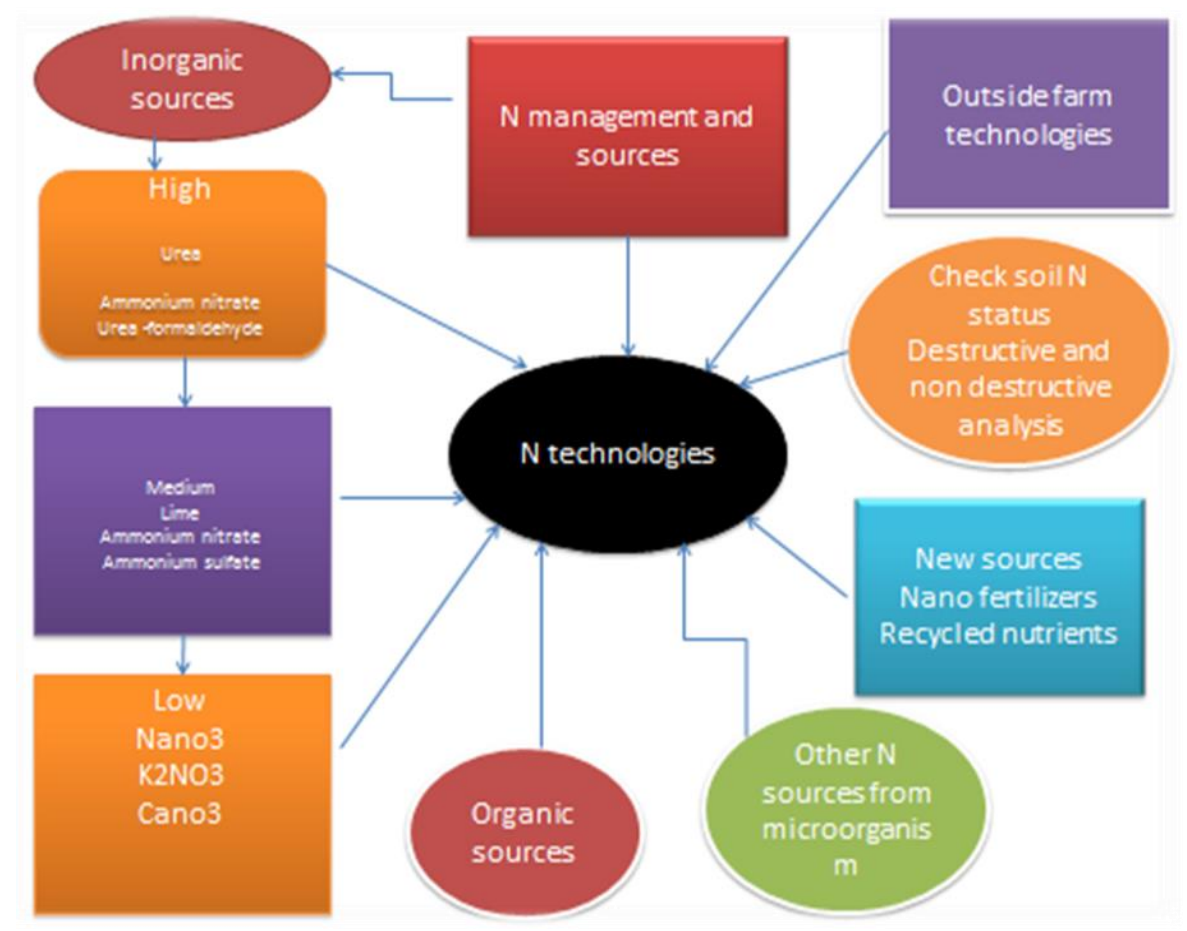

Figure 3. Nitrogen production sources and management

\section{Concluding remarks}

A genetic, physiological, and agronomic approach to $\mathrm{N}$ response and plant density will be useful for the use of NUE and is necessary to get key selection criteria for researchers and is important tool for farmers for fertilization protocol. This review will enhance the understanding to develop an integrated research work for discovering genes 
by means of a complete phenotypic, agronomical, physiological, and biochemical under different plant population densities. High population density, important for high yields, causes greater competition for resources and morphological changes in the plant and may lead kernel abortion and lodging. Under different plant populations, due to leaching of $\mathrm{NO}_{3}-\mathrm{N}$ and contamination of water the sufficient amount of $\mathrm{N}$ is not available to plant thus the NUE reduced. The future prospect is that how genetic, physiological, and agronomic approaches to high plant density and nitrogen to improve yield and quality of cereals. The breeders and agronomists should focus molecular and genetic aspects of cereals and should breed cultivars which are resistant to lodging and other problems under different plant densities.

Acknowledgements. We acknowledge the funding support from national modern agricultural industrial technology system project (CARS-06-13.5-A28), Youth fund of Crop Science, Shanxi Academy of Agricultural Sciences (ZQ1703), the Program for the Top Young Innovative Talents of Shanxi Agricultural University (TYIT201406).

\section{REFERENCES}

[1] Ahmed, S., Humphreys, E., Salim, M., Chauhan, B. S. (2016): Growth, yield and nitrogen use efficiency of dry-seeded rice as influenced by nitrogen and seed rates in Bangladesh. - Field Crops Research 186: 18-31.

[2] Anderson, R. L. (2008): Growth and yield of winter wheat as affected by preceding crop and crop management. - Agronomy Journal 100: 977-980.

[3] Borrell, A. K., Hammer, G. L., Van Oosterom, E. (2001): Stay-green: a consequence of the balance between supply and demand for nitrogen during grain filling. - Annals of Applied Biology 138: 91-95.

[4] Bos Bos, H. J. Vos, J., Struik, P. C. (2000): Morphological analysis of plant density effects on early leaf area growth in maize. - Netherlands Journal of Agricultural Science 48(2000): /99-212.

[5] Brennan, R. F., Mason, M. G., Walton, G. H. (2000): Effect of nitrogen fertilizer on the concentrations of oil and protein in canola (Brassica napus) seed. - Journal of Plant Nutrition 23: 339-348.

[6] Canevara, M. G., Romani, M., Corbellini, M., Perenzin, M., Borghi, B. (1994): Evolutionary trends in morphological, physiological, agronomical and qualitative traits of Triticum aestivum L. cultivars bred in Italy since 1990. - European Journal of Agronomy 3: $175-185$.

[7] Chapman, S., Baretto, H. (1997): Using a chlorophyll meter to estimate specific leaf nitrogen of tropical maize during vegetative growth. - Agronomy Journal 89: 557-562.

[8] Christopher, R. B., Judith, B. S., Tollenaar, M., Tony, J. V. (2009): Maize morphophysiological responses to intense crowding and low nitrogen availability: an analysis and review. - Agronomy Journal 101: 1426-1452.

[9] Ciampitti, I. A., Vyn, T. J. (2011): A comprehensive study of plant density consequences on nitrogen uptake dynamics of maize plants from vegetative to reproductive stages. Field Crops Research. 121(1):2-18.

[10] Comissão Brasileira de Pesquisa de Trigo (2007): Informaçõestécnicas da comissãobrasileira de Pesquisa de Trigo e Triticale para a Safra 2007 (Technical information from the Brazilian Wheat and Triticale Research Committee for the 2007 Season). - Embrapatrigo, Passo Fundo, RS, Brazil (in Portuguese).

[11] Dupont, F. M., Altenbach, S. B. (2003): Molecular and biochemical impacts of environmental factors on wheat grain development and during the life span of rice leaf (Oryza sativa L.). - Plant and Cell Physiology 24: 1079-1086. 
[12] Duvick, D. N. (1996): What is Yield? - In: Edmeades, G. O., Banziger, M., Mickelson, H. R., Peña-Valdivia, C. B. Developing Drought and Low N-Tolerant Maize. El Batain, Mexico.

[13] Dwyer, T., Ponsonby, A. L., Newman, N. M., Gibbons, L. E. (1991): Prospective cohort study of prone sleeping position and sudden infant death syndrome. - Lancet 337(8752): 1244-7.

[14] Feil, B., Thiraporn, R., Geisler, G. (1990): Genotypic variation in grain nutrient concentration in tropical maize grown during a rainy and a dry season. - Agronomie 10: 717-725.

[15] Gallais, A., Coque, M. (2005): Genetic variation and selection for nitrogen use efficiency in maize: a synthesis. - Maydica 50: 531-537.

[16] Gao, Y., Li, Y., Zhang, J., Liu, W., Dang, Z., Cao, W., Qiang, Q. (2009): Effects of mulch, $\mathrm{N}$ fertilizer, and plant density on wheat yield, wheat nitrogen uptake, and residual soil nitrate in a dryland area of China. - Nutrient Cycling in Agroecosystems 85(2): 109121.

[17] Gardner, J. C., Schnieter, A. A., Schatz, B. G. (2010): Effect of Plant Density on Grain Sorghum Production in North Dakota. - North Dakota Agricultural Experimental Station, Fargo, ND.

[18] Gastal, F., Lemaire, G. (2002): N uptake and distribution in crops: An agronomical and ecophysiological perspective. - Journal of Experimental Botany 53: 789-799. http://dx.doi.org/10.1093/jexbot/53.370.789.

[19] Giller, K. E., Beare, M. H., Lavelle, P., 'Izac, A.-M. N., Swift, M. J. (1997): Agricultural intensification, soil biodiversity and agroecosystem function. - Applied Soil Ecology 6: 3-16.

[20] Good, A. G., Shrawat, A. K., Muench, D. G. (2004): Can less yield more? Is reducing nutrient input into the environment compatible with maintaining crop production? Trends in Plant Science 9: 597-605.

[21] Halvorson, A. D., Wienhold, B. J., Black, A. L. (2001): Tillage and nitrogen fertilization influence grain and soil nitrogen in an annual cropping system. - Agronomy Journal 93: 836-841.

[22] Harris, D. A., Kim, K., Nakahara, K., Vásquez-Doorman, C., Carthew, R. W. (2011): Cargo sorting to lysosome-related organelles regulates sirna-mediated gene silencing. - J. Cell Biol. 194(1): 77-87.

[23] Hashemi, A. M., Herbert, S. J., Putnam, D. H. (2005): Yield response of corn to crowding stress. - Agronomy Journal 97 839-846.

[24] Hashemi-Dezfouli, A., Herbert, S. J. (1992): Intensifying plant population response of corn with artificial shade. - Agronomy Journal 84: 547-551.

[25] Hay, R. K. M., Walker, A. J. (1989): Introduction to the Physiology of Crop Yield. Longman Group UK Limited, Harlow.

[26] Hirel, B., Lea, P. (2001): Ammonia Assimilation. - In: Lea, P. J., Morot-Gaudry, J. F. (eds.) Plant Nitrogen. Springer-Verlag, Berlin, pp. 79-100. http://dx.doi.org/10.1007/9783-662-04064-5_4.

[27] Hou H., Ma W., Noor, M.A., Tang L., Li C., Ding Z., Zhao M. (2019): Quantitative design of yield components to simulate yield formation for maize in China - Journal of Integrative Agriculture 18: 2-13. https://doi.org/ 10.1016/S2095-3119(19)62661-4

[28] Huseyin, G. K., Omer, M. K. (2003): Effect of hybrid and plant density on grain yield and yield components of maize (Zea mays L.). - Indian J. Agron. 48 203-205.

[29] Jackson, G. D. (2000): Effects of nitrogen and sulfur on canola yield and nutrient uptake. - Agronomy Journal 92: 44-49.

[30] Jamaati-e-Somarin, S., Zabihi-e-Mahmoodabad, R., Yari, A., Khayatnezhad, M., Gholamin, R. (2010): Study of Agronomical Nitrogen Use Efficiency of Durum Wheat, Affected by Nitrogen Fertilizer and Plant Density. - World Applied Sciences Journal 11(6): 674-681. 
[31] Jan, M. T., Khan, J. M., Khan, A., Arif, M., Shafi, M., Nullah, N. (2010): Wheat nitrogen indices response to nitrogen source and application time. - Pakistan Journal of Botany 42(6): 4267-4279.

[32] Jiang, W., Wang, K., Wu, Q., Dong, S., Liu, P., Zhang, J. (2013): Effects of narrow plant spacing on root distribution and physiological nitrogen use efficiency in summer maize. The Crop Journal 1(1): 77-83.

[33] Kade, M., Barneix, A. J., Olmos, S., Dubcovsky, J. (2005): Nitrogen uptake and remobilization in tetraploid 'Langdon' durum wheat and a recombinant substitution line with the high grain protein gene Gpc-B1. - Plant Breeding 124: 343-349.

[34] Keesstra, S. D. et al. (2016): Interactive comment on "FORUM" paper: The significance of soils and soil science towards realization of the UN sustainable development goals (SDGS). - Soil Discuss. DOI: 10.5194/soil-2015-88-AC1.

[35] Lea, P. J., Azevedo, R. A. (2006): Nitrogen use efficiency. 1. Uptake of nitrogen from the soil. - Annals of Applied Biology 149: 243-247.

[36] Li, J., Xie, R. Z., Wang, K. R., Ming, B., Guo, Y. Q., Zhang, G. Q., Li, S. K. (2015): Variations in maize dry matter, harvest index, and grain yield with plant density. - Agron. J. 107: 829. http://dx.doi.org/10.2134/agronj14.0522.

[37] Li, M., Li, W. (2004): Regulation of fertilizer and density on sink and source and yield of maize. - Sci. Agric. Sin. 37(8): 1130-1137 (in Chinese).

[38] Li, S. K., Wang, C. T. (2010): Potential and Ways to High Yield in Maize. - Science Press, Beijing, pp. 217-240 (in Chinese).

[39] Liu, W., Tollenaar, M., Stewart, G., Deen, W. (2004): Response of corn grain yield to spatial and temporal variability in emergence. - Crop Science 44: 847-854.

[40] Lopez-Bellido, R. J., Shepherd, C. E., Barraclough, P. B. (2004): Predicting post-anthesis $\mathrm{N}$ requirements of bread wheat with Minolta SPAD meter. - European Journal of Agronomy 20(3)313-320.

[41] Maddonni, G. A., Otegui, M. E., Cirilo, A. G. (2001): Plant population density, row spacing, and hybrid effects on maize canopy architecture and light attenuation. - Field Crops Research 71: 183-193.

[42] Mae, T. (1997): Physiological nitrogen efficiency in rice: nitrogen utilization, photosynthesis, and yield potential. - Plant and Soil 196(2): 201-211.

[43] Moose, S., Below, F. E. (2009): Biotechnology Approaches to Improving Maize Nitrogen Use Efficiency. - In: Kriz, A. L., Larkins, B. A. (eds.) Molecular Genetic Approaches to Maize Improvement, Biotechnology in Agriculture and Forestry. Springer-Verlag, Berlin, pp. 65-77.

[44] Noor, M. A. (2017): Nitrogen management and regulation for optimum NUE in maize A mini review - Cogent Food \& Agriculture, 3: 1348214.

[45] Oury, F. X., Be'rard, P., Brancourt-Hulmel, M., et al. (2003): Yield and grain protein concentration in bread wheat: a review and a study of multi-annual data from a French breeding program. - Journal of Genetics and Breeding 57: 59-68.

[46] Palta, J. A., Fillery, I. R. P. (1995): N application increases pre-anthesis contribution of dry matter to grain yield in wheat grown on duplex soil. - Australian Journal of Agricultural Research 46: 507-518.

[47] Pearcy, R. W., Valladares, F., Wright, S. J., Lasso de Paulis, E. (2004): A functional analysis of the crown architecture of tropical forest psychotria species: do species vary in light capture efficiency and consequently in carbon gain and growth? - Oecologia139: 163-177.

[48] Radenovic, C., Konstantinov, K., Delic, N., Stankovic, G. (2007): Photosynthetic and biolumine science properties of maize inbred lines with upright leaves. - Maydica 52: 347-356.

[49] Rajcan, I., Tollenaar, M. (1999). Source:sink ratio and leaf senescence in maize. II. Nitrogen metabolism during grain filling. - Field Crops Research 60: 255-265. 
[50] Rampino, P., Pataleo, S. Gerardi, C., Carla Perrotta, G. (2006): Drought stress response in wheat: physiological and molecular analysis of resistant and sensitive genotypes. - Plant, Cell and Environment 29: 2143-2152.

[51] Raun, W. R., Johnson, G. V. (1999): Improving nitrogen use efficiency for cereal production. - Agronomy Journal 91: 357-363.

[52] Remans, T., Nacry, P., Pervent, M., Girin, T., Tillard, P., Lepetit, M., Gojon, A. (2006): A central role for the nitrate transporter NRT2.1 in the integrated morphological and physiological responses of the root system to nitrogen limitation in Arabidopsis. - Plant Physiol. 140(3): 909-21.

[53] Riedell, W. E., Pikul, J. L., Jaradat, A. A., Schumacher, T. E. (2009): Crop rotation and nitrogen input effects on soil fertility, maize mineral nutrition, yield and seed composition. - Agronomy Journal 101: 870-879.

[54] Sangoi, L., Gracietti, M. A., Rampazzo, C., Bianchetti, P. (2002): Response of Brazilian maize hybrids from different eras to changes in plant density. - Field Crops Research 79: $39-51$.

[55] Sharratt, B. S., Mcwilliams, D., (2005): Microclimatic and rooting characteristics of narrow-row versus conventional-row corn. - Agronomy Journal 97: 1129-1135. http://dx.doi.org/10.2134/agronj2004.0292.

[56] Sher, A., He, L., Zhang, S., Li, J. C., Song, Y. (2016): Analysis and characterisation of interplant competition on maize canopy morphology for modelling. - In: Proceedings of the IEEE International Conference on Functional- Structural Plant Growth Modeling, Simulation, Visualization and Applications (FSPMA), Qingdao, pp. 189-193. DOI: 10.1109/FSPMA.2016.7818306.

[57] Sher, A., Khan, A., Li, J. C., Ahmad, M. I., Asharf, U., Jamoro, S. A. (2017): Response of maize grown under high plant density; performance, issues and management - a critical review. - Adv Crop Sci Tech. 5: 3.

[58] Sher, A., Khan, A., Liu, H. H., Ashraf, U., Li, J. C. (2018): Characterization of the effect of increased plant density on canopy morphology and stalk lodging risk. - Front. Plant Sci. 9: 1047.

[59] Simmonds, N. W. (1995): The relation between yield and protein in cereal grains. Journal of the Science of Food and Agriculture 67: 309-315.

[60] Sinclair, T. R., Purcell, L. C., Sneller, C. H. (2004): Crop transformation and the challenge to increase yield potential. - Trends in Plant Science 9: 70-75.

[61] Smil, V. (2006): Transforming the 20th Century. - Oxford University Press, New York.

[62] Snyder, F. W., Bunce, J. A. (1983): Use of the plastochron index to evaluate effects of light, temperature and nitrogen on growth of soya bean (Glycine max L. Merr.). - Annals of Botany 52: 895-903.

[63] Soleymani, A., Shahrajabian, M. H., Naranjani, L. (2011): Determination of the suitable planting date and plant density for different cultivars of barley (Hordeum vulgare L.) Fars. African Journal of Plant Science 5(4): 284-286.

[64] Stewart, D. W., Costa, C., Dwyer, L. M. Smith, D. L. Hamilton, R. I. Ma, B. L. (2003): Canopy structure, light interception, and photosynthesis in maize. - Agronomy Journal 95: 1465-11474.

[65] Sylvester-Bradley, R., Kindred, D. R. (2009): Analysing nitrogen responses of cereals to prioritize routes to the improvement of nitrogen use efficiency. - Journal of Experimental Botany 60: 1939-1951. http://dx.doi.org/10.1093/jxb/erp116.

[66] Ta, C. T., Weiland, R. T. (1992): Nitrogen partitioning in maize during ear development. - Crop Science 32: 443-451.

[67] Tabuchi, M., Sugiyama, T., Ishiyama, K., Inoue, E., Sato, T., Takahashi, H., Yamaya, T. (2005): Severe reduction in growth and grain filling of rice mutants lacking osgs 1;1, a cytosolic glutamine synthetase 1;1. - The Plant Journal 42: 641-655. 
[68] Tang, L., Ma, W., Noor, M.A., Li, L., Hou, H., Zhang, X., Zhao, M. (2018): Density resistance evaluation of maize varieties through new "Density-Yield Model" and quantification of varietal response to gradual planting density pressure - Scientific Reports, 8:17281. DOI:10.1038/s41598-018-35275-w

[69] Tanner, D., Amanuel, G., Asefa, T. (1993): Fertilizer effect on sustainability in the Wheat based small holder-farming systems of southeastern Ethiopia. - Field Crops Research 33: 235-248.

[70] Teklu, E., Hailemariam, T. (2009): Agronomic and economic efficiency of manure and urea fertilizers use on vertisols in Ethiopian highlands. - J. Agri. Sci. 8(3): 352-360.

[71] Tetio-Kagho, F., Gardner, F. (1988): Responses of maize to plant population density. I. Canopy development, light relationships, and vegetative growth. - Agronomy Journal 80: 930-935.

[72] Thuy, N. H., Shan Y., Singh B., Wang K., Cai Z., Singh Y., Buresh, R. J. (2008): Nitrogen supply in rice-based cropping systems as affected by crop residue management. - Soil Sci Soc Am J 72:.

[73] Tokatlidis, I. S., Has, V. Melidis, V. Has. I. Melonas, I., Evgenidis, G. Copandean, A., Ninou, E. Fasoula, V. A. (2011): Maize hybrids less dependent on high plant densities improve resource use efficiency in rainfed and irrigated conditions. - Field Crops Research 120. 345-351.

[74] Tollenaar, M., Wu, J. (1999): Yield improvement in temperate maize is attributable to greater stress tolerance. - Crop Science 39: 1597-1604.

[75] Tollenaar M., Dwyer, L. M., Stewart, D. W., (1992): Ear and kernel formation in maize hybrids representing three decades of grain yield improvement in Ontario. - Crop Science 32: 432-438.

[76] Tollenaar, M., Deen, W., Echarte, L., Liu, W. (2006): Effect of crowding stress on dry matter accumulation and harvest index in maize. - Agronomy Journal 98: 930-937. Doi: 10.2134/agronj2005.0336.

[77] Trapani N., Hall, A. J. (1996): Effects of leaf position and nitrogen supply on the extension of leaves of field-grown sunflower (Helianthus annuus L.). - Plant and Soil 184: 331-340.

[78] UNEP, UNIDO, IFA. (1998): Mineral Fertilizer Production and the Environment. Part 1. The fertilizer industry's Manufacturing Processes and Environmental Issues. Fertilizer Technical Report. - International Fertilizer Industry Association, United Nations Environment Programme, Paris, pp. 1-66.

[79] Uribelarrea M., Below, F. E., Moose, S. P. (2007): Divergent selection for grain protein affects nitrogen use in maize. - Field Crops Research 100: 82-90.

[80] USDA NASS (1965-2009): Compilation of Crop Production Reports. Agri-News. 09-18. - http://www.nass.usda.gov (verified 1 May 2001). USDA-NASS, Washington, DC.

[81] USDA-National Agricultural Statistics Service (2010): Published Estimates Data Base (PEDB). - http://www.nass.usda.gov (verified 1 May 2001). USDA-NASS, Washington, DC.

[82] Valladares, F., Niinemets, U. (2008): Shade tolerance, a key plant feature of complex nature and consequence. - Annual Review Ecology Systematics 257. https://doi.org/10.1146/annurev.ecolsys.39.110707.173506.

[83] Vos J., Biemond, H. (1992): Effects of nitrogen on the development and growth of the potato plant. 1. Leaf appearance, expansion growth, life span of leaves and stem branching. - Annals of Botany 70: 27-35.

[84] Wang, X., Yue, Y., Noor, M. A., Hou, H., Zhou, B., Ma, W., Zhao, M. (2018): Tillage time affects soil hydro-thermal properties, seedling growth and yield of maize (Zea mays L.). - Applied Ecology and Environmental Research 16(5): 6007-6023.

[85] White, P. J., Brown, P. H (2010): Plant nutrition for sustainable development and global health. - Annals of Botany 105(7): 1073-1080. 
[86] Widdicombe, W. D., Thelen, K. D. (2002): Row width and plant density effects on corn grain production in the Northern Corn Belt. - Agronomy Journal 94: 1020-1023.

[87] Yu, Q., Wang, T., Liu, J., Sun, S (1998): Mathematical study on crop architecture and canopy photosynthesis. - J. Model. Acta. Agric. Sin. 24(1): 7-15 (in Chinese).

[88] Zhu, Z. (2000): Loss of fertilizer N from the plant-soil system and the strategies and techniques for its reduction in China. - Soil Environmental Science 9: 1-6. 